MINERALOGIA, 46, No 1-2: 19-28 (2015)

DE DE GRUYTER OPEN

Original paper

\title{
Green to blue-green quartz from Rakowice Wielkie (Sudetes, south-western Poland) - a re-examination of prasiolite-related colour varieties of quartz
}

\author{
Alexej N. Platonov ${ }^{1}$, Adam Szuszkiewicz ${ }^{2 *}$ \\ ${ }^{1}$ Institute of Geochemistry, Mineralogy and Ore Formation, Academy of Science of Ukraine, Palladina 34, \\ 252680 Kiev-142, Ukraine \\ ${ }^{2}$ Institute of Geological Sciences, University of Wrockaw, 50-204 Wrockaw, pl. M. Borna 9, Poland \\ e-mail: adam.szuszkiewicz@uwr.edu.pl \\ * Corresponding author
}

Received: March 9, 2016

Received in revised form: April 26, 2016

Accepted: May 26, 2016

Available online: September 25, 2016

\begin{abstract}
The green colour of prasiolite, defined as naturally occurring transparent macrocrystalline $\alpha$-quartz with primary colouration, results from the optical absorption centred at $\sim 13,660 \mathrm{~cm}^{-1}$ and attributed to the $\mathrm{Fe}_{\mathrm{VI}}^{2+} \rightarrow \mathrm{Fe}_{\mathrm{VI}}{ }^{3+}$ intervalence charge transfer (Platonov et al. 1992). However, optical absorption spectroscopy of blue-green to green quartz from Rakowice Wielkie, Sudetes, south-western Poland, shows that its primary colouration results from the combination of this band and absorptions at $\sim 18,500 \mathrm{~cm}^{-1}$ and $\sim 16,250 \mathrm{~cm}^{-1}$. The first is assigned to a hole centre $\mathrm{Fe}^{4+}{ }_{s}\left(\mathrm{Fe}^{3+}{ }_{\mathrm{s}} \mathrm{e}^{-}\right)$combined with an electron centre $\mathrm{Fe}^{2+}{ }_{16}\left(\mathrm{Fe}^{3+}{ }_{16}+\mathrm{e}^{-}\right)$, while the second from $\mathrm{AlO}_{4}{ }^{4}$ defects. The quartz is blue-green if the $18,500 \mathrm{~cm}^{-1}$ prevails and becomes pale green if the $16,250 \mathrm{~cm}^{-1}$ band predominates. These colours seem to represent intermediate colour varieties between amethyst and prasiolite. We also suggest that spectral features of coloured quartz varieties might be useful indicators of changes in the physical- and chemical characteristics of the mineral-forming fluids.
\end{abstract}

Key-words: prasiolite, green quartz, optical absorption, Rakowice Wielkie, Sudetes

\section{Introduction}

Macrocrystalline green quartz from the Sudetes, south-western Poland was described by Heinrich Fiedler over 150 years ago (Fiedler 1863). The samples characterized by Fiedler 
are stored under the original author's name of "green amethyst" in the Mineralogical Museum of the University of Wrocław. For a long time, the terms "green amethyst" and "greened amethyst" were used in mineralogy and especially in gemmology as synonyms of prasiolite - an idiochromatic green variety of quartz, because of a common belief that the colour of prasiolite is a secondary effect of heating of amethyst (for details see Paradise 1982; Platonov et al. 1992; Rossman 1994). However, it has been shown that the colouration of some naturally occurring prasiolites, e.g. from the Suszyna-Mrówieniec area and Płóczki Górne (Poland), Bahia (Brazil), Thunder Bay (Canada) and Farm Rooisand (Namibia), is a primary feature (Hebert, Rossman 2008; Platonov et al. 1992; Sachanbiński et al. 1994). The green colour results from the absorption band at $13,660 \mathrm{~cm}^{-1}(\sim 710-$ $730 \mathrm{~nm}$ ) that dominates the optical spectrum and seems to be diagnostic for prasiolite defined as naturally occurring transparent macrocrystalline $\alpha$-quartz with primary green colouration (Platonov et al. 1992).

However, the primary bluish-green to green colour of quartz from Rakowice Wielkie (Sudetes, south-western Poland) has been found to result from other optical absorption bands (Platonov et al. 1991) and, thus, does not accord with the definition of prasiolite above. In order to study the different causes of green colouration in naturally occurring macrocrystalline quartz in detail, we re-examined the optical absorption characteristics of quartz samples from Rakowice Wielkie, and from the Suszyna-Mrówieniec area previously investigated by Platonov et al. (1991, 1992). Newly obtained spectral parameters of the bluish-green and pale-green sectors of colour-zoned quartz from Rakowice Wielkie were compared to similar values of the prasiolite sensu stricto from the Suszyna-Mrówieniec area. The results are discussed in terms of the causes of various quartz colourations and of the significance of colour as an indicator of the physical- and chemical parameters of the mineral-forming systems.

\section{Occurrences of green quartz in Poland and sample description}

In Poland, prasiolite occurs only in the Sudetes at the NE margin of the Variscan Bohemian Massif. Occurrences of prasiolite are concentrated in the Intra- and NorthSudetic basins, two large intramontane troughs formed during late stages of the Variscan orogeny that are filled with Permo-Carboniferous molasse deposits interstratified with bimodal volcanics and overlain by younger sediments (Fig. 1). Prasiolite is associated with agate-quartz mineralization developed locally in Permian basaltic andesites and basaltic trachyandesites (for details on geology and further references see Awdankiewicz 1999a, 1999b, 2006; Madej 1998). The prasiolite-bearing occurrences are located in the area near Mrówieniec and Suszyna in the Intra-Sudetic Basin, and in the vicinity of Płóczki Górne and Sokołowiec in the North-Sudetic Basin (Platonov et al. 1992; Praszkier et al. 2011, 2015). Redeposited fragments of agate-quartz geodes with green quartz are also known from sand and gravel deposits at Rakowice Wielkie near Lwówek Śląski in the NorthSudetic Basin (Platonov et al. 1991; Praszkier et al. 2011). The Rakowice Wielkie sandand gravel pit is situated in the riverbed and Pleistocene-Holocene terraces of the Bóbr River. The gravel, containing only limited amounts of glacially-derived clasts, consist mostly of poorly sorted fragments of various crystalline- and sedimentary rocks of the 
North-Sudetic Basin, although material from more distant geological units of the Sudetes is also present (Buksiński, Cegła 1979).

The two investigated samples are green to bluish-green quartz from Rakowice Wielkie (QR) and olive-green prasiolite from Mrówieniec (PM). Both were used in previous studies (QR in Platonov et al. 1991 and PM in Platonov et al. 1991, 1992). Sample QR was collected from tailings of the sand- and gravel pit near Rakowice Wielkie, $\sim 5 \mathrm{~km} \mathrm{NW}$ from Lwówek Śląski, Sudetes, SW Poland (Fig. 1). QR is a few-centimetre fragment of a quartzagate geode filled, from the margin inwards, by a chalcedony rim $(<0.5 \mathrm{~cm}$ thick $)$ overgrown by fine-grained colourless quartz and, finally, by crystals of quartz $<1.5 \mathrm{~cm}$ long with colouration varying from green to pale blue-green. Because the QR sample was destroyed in the process of preparing polished plates for spectroscopic studies, the photograph in Figure 2a is of a similar, though not identical, geode collected at Rakowice Wielkie.

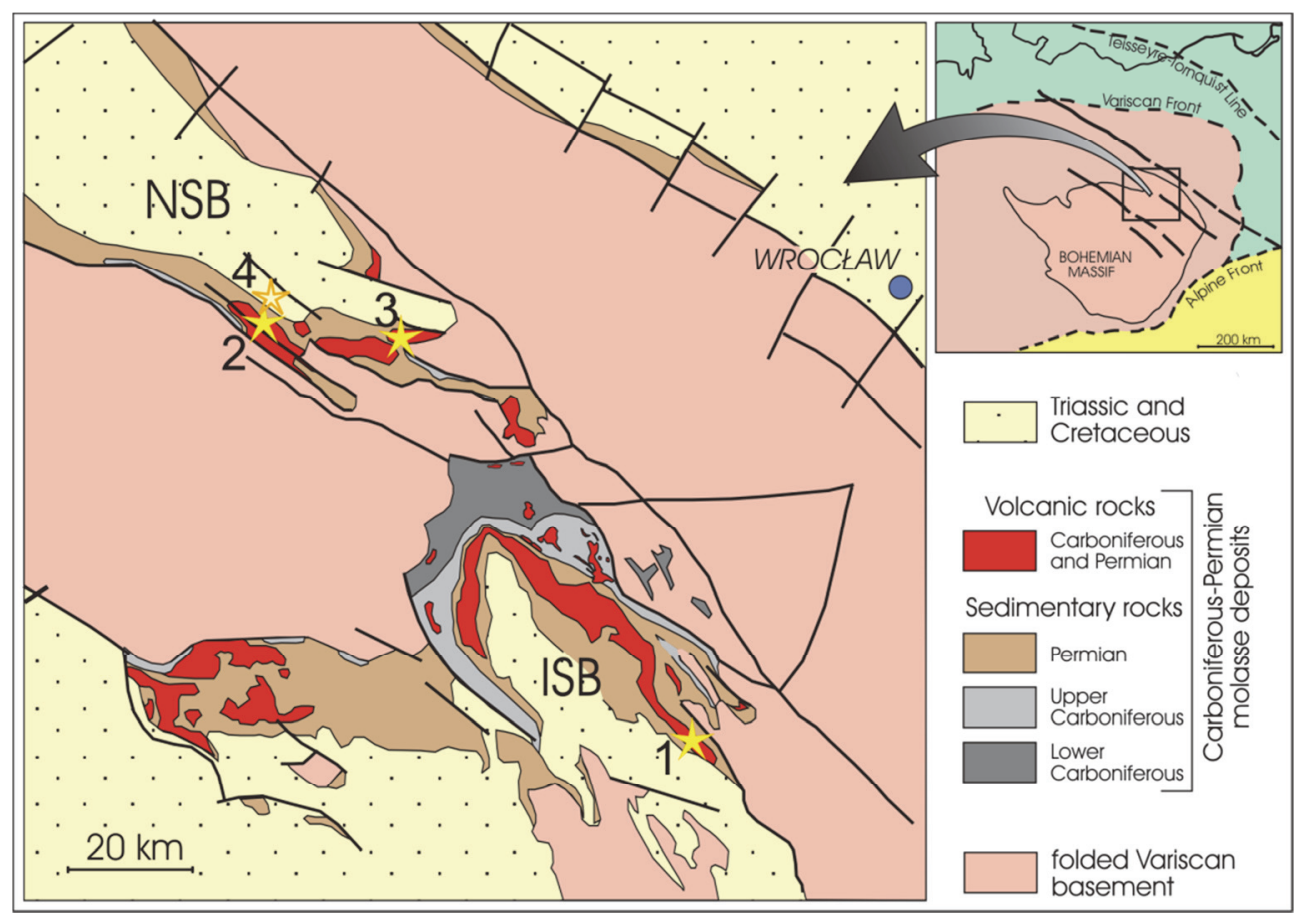

Fig. 1. Geological sketch map of the Sudetes without the Cainozoic deposits (Awdankiewicz 2006) showing the occurrences of prasiolite. 1: Suszyna-Mrówieniec area, 2: Płóczki Górne, 3: Sokołowiec, 4: Rakowice Wielkie, ISB: Intra-Sudetic Basin, NSB: North-Sudetic Basin, filled stars: in situ occurrences, empty star: sand and gravel deposit at Rakowice Wielkie. 
A

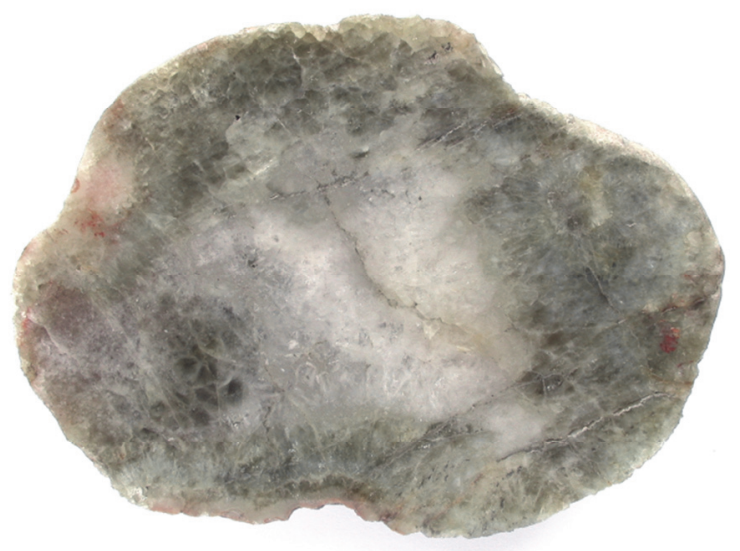

B

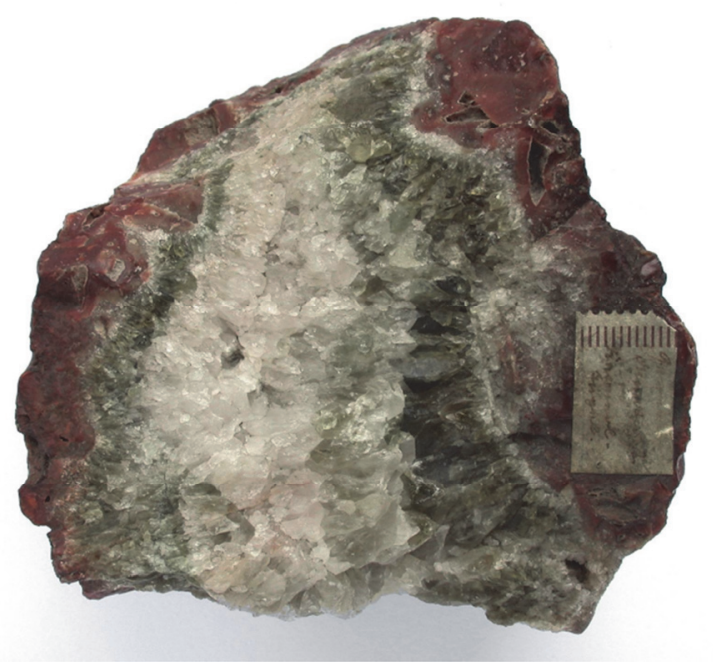

Fig. 2. A: Section through an agate-quartz geode with sectors of bluish-green and pale-green macrocrystalline quartz from Rakowice Wielkie, similar, though not identical, to the studied specimen. The geode is $<13 \mathrm{~cm}$ in size. B: Prasiolite in a quartz-agate geode $<10 \mathrm{~cm}$ in size from the Suszyna-Mrówieniec area. The specimen is stored under the catalogue number MMWrIII-158 in the Mineralogical Museum of the University of Wrocław.

The PM sample, stored in the Mineralogical Museum of the University of Wrocław under the catalogue number MMWrIII-158, was collected in a field near Mrówieniec, $\sim 10 \mathrm{~km} \mathrm{NW}$ from Kłodzko (Fig. 1). It is a part of a $6 \times 10 \mathrm{~cm}$ geode weathered out from underlying basaltic andesites and basaltic trachyandesites. The outer part of the geode is composed of brick-red chalcedony with $<5 \mathrm{~mm}$ negative crystal voids probably after leached calcite, whereas the centre is filled with macrocrystalline quartz (Fig. 2b). The quartz filling is colour-zoned with a 1-2 mm outermost band of colourless to greyish 
quartz, overgrown by a $<1 \mathrm{~cm}$ band of olive-green quartz and an innermost zone of colourless quartz. The distribution of colour in the prasiolite crystals is slightly patchy, varying from green-brownish and olive-green in the crystal roots to pure green near the terminations. Other geodes with silica minerals from this locality also contain minor palecoloured amethyst, albite, laumontite, stilbite, epistilbite, heulandite, thomsonite (?), celadonite, calcite and goethite.

\section{Analytical methods}

Polished plates of the quartz samples were cut so that the optical absorption spectra could be measured with the light polarized parallel $(E \| c)$ and perpendicular $(E \perp c)$ to the $c$ axis. The bluish-green and green sectors of $\mathrm{QR}$ were measured separately and are referred to as QR-blue and QR-green, respectively. The measurements were carried out using a nonserial micro-spectrometer at the Institute of Geochemistry and Physics of Minerals, Academy of Sciences of Ukraine in Kiev, Ukraine. The E\|c and E $\perp c$ optical absorption spectra were recorded at room temperature in the spectral range of $26,300-9000 \mathrm{~cm}^{-1}(380$ $1100 \mathrm{~nm}$ ) with measurement steps of $1 \mathrm{~nm}$. The spectra are plotted as the specific absorbance $\mathrm{K}(\lambda)=\log \left(\mathrm{I}_{0} / \mathrm{I}\right) / \mathrm{d}$, where $\mathrm{K}$ is a linear absorption coefficient for monochromatic radiation, $\mathrm{I}_{0}$ and $\mathrm{I}$ are intensities of monochromatic radiation without and with a sample, respectively, and $\mathrm{d}$ is the sample thickness in $\mathrm{cm}$. The spectra were resolved into elemental absorption bands whose spectroscopic parameters such as wavenumber $\left(\mathrm{v}, \mathrm{cm}^{-1}\right)$, intensity $\left(\mathrm{K}, \mathrm{cm}^{-1}\right)$ and half-width $\left(\Delta_{\mathrm{v} 1 / 2}, \mathrm{~cm}^{-1}\right)$ were determined using the deconvolution procedure in the Peakfit 4.11 software package (Systat Software Inc., Chicago). The short-wave region with the intense UV absorption, that constitutes the background of the spectra in the visible- and near IR regions, was modelled using Gaussian-Lorenzian mixed functions. The absorption bands were fitted using Gaussian distributions.

\section{Results and discussion}

The Figure 3 presents deconvoluted E\|c-spectra of PM, QR-green and QR-blue. The spectra consist of six distinct broad absorption bands superimposed on the tail of a very intensive absorption band centred in the UV region. The absorption bands are approximately centred at: 23,100 $\mathrm{cm}^{-1}$ (a-band), 21,200 $\mathrm{cm}^{-1}$ (b-band), 18,500 $\mathrm{cm}^{-1}$ (c-band), 16,250 $\mathrm{cm}^{-1}$ (d-band), 13,660 $\mathrm{cm}^{-1}$ (e-band), and 10,700 $\mathrm{cm}^{-1}$ ( $f$-band), with the exact positions being slightly dependent on the sample and on polarization direction (Table 1). The half-widths $\left(\Delta_{\mathrm{v} 1 / 2}\right)$ of the most prominent bands are: $3400-3700 \mathrm{~cm}^{-1}$

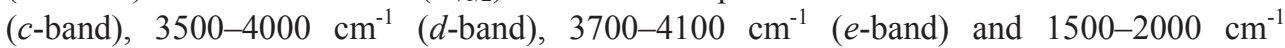
(f-band).

In the short-wave region, two broad $a$ - and $b$-bands probably represent the so-called $\mathrm{A}_{2}$ and $\mathrm{A}_{3}$ bands (or their varieties) commonly identified in optical spectra of quartz with irradiation-induced colours, and related to hole centres in the quartz structure (Nassau, Prescott 1977; Partlow, Cohen 1986). 


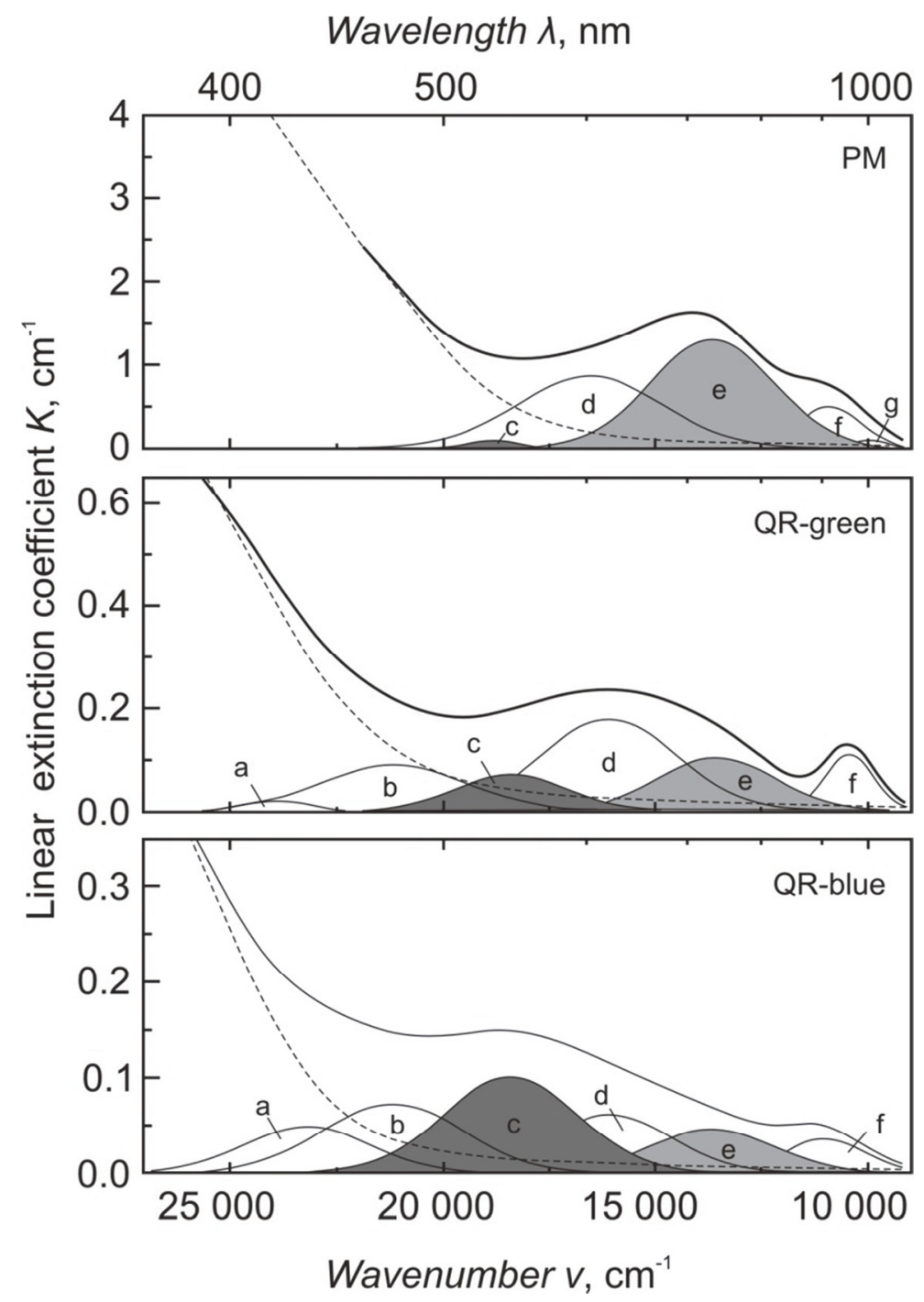

Fig. 3. The E\|c -polarized optical absorption spectra of blue-green (QR-blue) and green (QR-green) quartz from Rakowice Wielkie and of green prasiolite (PM) from the Suszyna-Mrówieniec area.

The $c$-band is commonly observed in optical absorption spectra of natural- and synthetic amethysts. The band is associated with the "amethyst colour centre" that, in accordance with a widely accepted model, consists of a donor-acceptor pair that consists of a hole centre $\mathrm{Fe}^{4+}{ }_{\mathrm{s}}\left(\mathrm{Fe}^{3+}{ }_{\mathrm{s}}-\mathrm{e}^{-}\right)$and an electron centre $\mathrm{Fe}^{2+}{ }_{\mathrm{I} 6}\left(\mathrm{Fe}^{3+}{ }_{\mathrm{I} 6}+\mathrm{e}^{-}\right)$(Lehmann 1975; Neumann, Schmetzer 1984). Heating the quartz up to $350-400^{\circ} \mathrm{C}$ results in the re-combination of electrons and holes, oxidation of a part of iron and the formation of structural and interstitial $\mathrm{Fe}^{3+}$ ions that are precursors of the so-called "prasiolite" and "green amethyst" colour centres (Neumann, Schmetzer 1984). Thus, there is a good reason to specify the $c$ band as the "amethyst absorption band". 
Table 1. The spectral position (wavenumber, $\mathrm{cm}^{-1}$ ) of the optical absorption spectra of green- and blue-green quartz (QR-green and QR-blue, respectively) from quartz-agate geodes from Rakowice Wielkie (Lower Silesia, SW Poland).

\begin{tabular}{llllllll}
\hline \multirow{2}{*}{ Samples } & \multirow{2}{*}{ Polarization } & \multicolumn{6}{c}{ Wavenumbers of the absorption bands, $\mathrm{cm}^{-1}$} \\
\cline { 3 - 8 } & & $\mathbf{a}$ & $\mathbf{b}$ & $\mathbf{c}$ & $\mathbf{d}$ & $\mathbf{e}$ & $\mathbf{f}$ \\
\hline \multirow{2}{*}{ QR-green } & $\mathrm{E} \| \mathrm{c}$ & 22,900 & 21,200 & 18,420 & 16,120 & 13,570 & 10,450 \\
\cline { 2 - 8 } & $\mathrm{E} \perp \mathrm{c}$ & 22,880 & 21,200 & 18,550 & 16,450 & 13,570 & 10,400 \\
\hline \multirow{2}{*}{ QR-blue } & $\mathrm{E} \| \mathrm{c}$ & 23,400 & 21,800 & 18,550 & 16,230 & 13,780 & 10,960 \\
\cline { 2 - 8 } & $\mathrm{E} \perp \mathrm{c}$ & 23,200 & 21,200 & 18,440 & 16,090 & 13,690 & 11,030 \\
\hline Average & & 23,100 & 21,200 & 18,500 & 16,250 & 13,660 & 10,700 \\
\hline
\end{tabular}

The broad $d$-band most probably corresponds to the so-called $\mathrm{A}_{1}$ band near 15,900 $14,900 \mathrm{~cm}^{-1}(620-660 \mathrm{~nm})$ that is related to a variety of $\mathrm{O}^{-}-\mathrm{Al}$ hole centres. According to Schmetzer (1989), the band plays a crucial role in the colouration of natural olive-green quartz (greenish citrine). Similar green- and olive-green colours can be obtained artificially by heating irradiated smoky quartz (e.g. Nassau, Prescott 1977). These hole centres probably participate in the electron-hole configurations that lead to the formation of $\mathrm{Fe}$ related colour centres.

The broad $e$-band shows a half-width value $\left(\Delta_{\mathrm{v} 1 / 2}\right)$ of $\sim 3700-4100 \mathrm{~cm}^{-1}$, too large for $d$ - $d$ electron transitions in interstitial of $\mathrm{Fe}^{2+}$ ions that are generally responsible for the appearance of the so-called "green absorption band" in optical spectra of many natural prasiolites and "green amethysts" (e.g. Lehmann 1967; Lehmann, Bambauer 1973; Neumann, Schmetzer 1984). Platonov et al. (1992) attributed the $e$-band in the PM to the intervalence charge transfer $\mathrm{Fe}_{\mathrm{VI}}{ }^{2+} \rightarrow \mathrm{Fe}_{\mathrm{VI}}{ }^{3+}$. In any case, the $e$-band can be designated as a "prasiolite band".

The $f$-band should be attributed to $\mathrm{Fe}^{2+}$-ion absorption and the $\Delta_{\mathrm{v} 1 / 2}$ of $\sim 1500-2000 \mathrm{~cm}^{-1}$ is typical for $d d$-transitions in $\mathrm{Fe}^{2+}$-ions in the octahedral crystal field. Relative intensities of $d$ - and $f$-bands are highly variable (compare the spectra of QR-green and PM in Fig. 3), suggesting different causes for these absorptions.

In general, the colour of QR and PM results from the maximum transmission of light in the green range at $\sim 18,500 \mathrm{~cm}^{-1}$ (Fig. 3). However, because the transmission "window" is defined by the superimposed $c$-, $d$ - and $e$-bands, variations in the relative intensities of these bands modify the colour. The comparison of the intensities of the $c$-, $d$ - and $e$-bands $\left(K_{c}, K_{d}\right.$ and $K_{e}$, respectively) normalized to $K_{c}$ shows that the proportions of the relative intensities $K_{c}: K_{d}: K_{e}$ in the obtained spectra are highly variable:

QR-blue - $1: 0.6: 0.45$; QR-green - $1: 2.5: 1.4$; PM - $1: 9.4: 14.3$.

In the spectrum of bluish-green sectors of QR (QR-blue), the $c$-band at $\sim 18,500 \mathrm{~cm}^{-1}$ prevails and shifts the maximum absorption to $\sim 18,200 \mathrm{~cm}^{-1}$ and the maximum transmission toward the blue-green range. On the other hand, in the spectrum from green sectors of QR (QR-green), the $d$-band at $\sim 16,250 \mathrm{~cm}^{-1}$ is the most intensive and the maximum absorption is shifted to $\sim 15,900 \mathrm{~cm}^{-1}$, whereas the transmission "window" moves toward the green range. In the spectrum of PM, the $e$-band at $\sim 13,660 \mathrm{~cm}^{-1}$ dominates and 
is largely responsible for the maximum absorption being located at $\sim 14,050 \mathrm{~cm}^{-1}$. As a result, the maximum transmission takes place in the yellow-green range.

The green colour of the PM has been shown to be primary and not a result of thermal bleaching of amethyst (Platonov et al. 1992). On the other hand, the bluish-green and palegreen colours of QR-blue and QR-green from Rakowice Wielkie, respectively, may represent intermediate colour varieties between amethyst and prasiolite. Such an interpretation is supported by the results of heating experiments (Platonov et al. 1991). On heating at $400^{\circ} \mathrm{C}$ for an hour, the "amethyst band" ( $c$-band) completely annealed, whereas the intensity of the "prasiolite band" (e-band) strongly increased. As a result, the optical

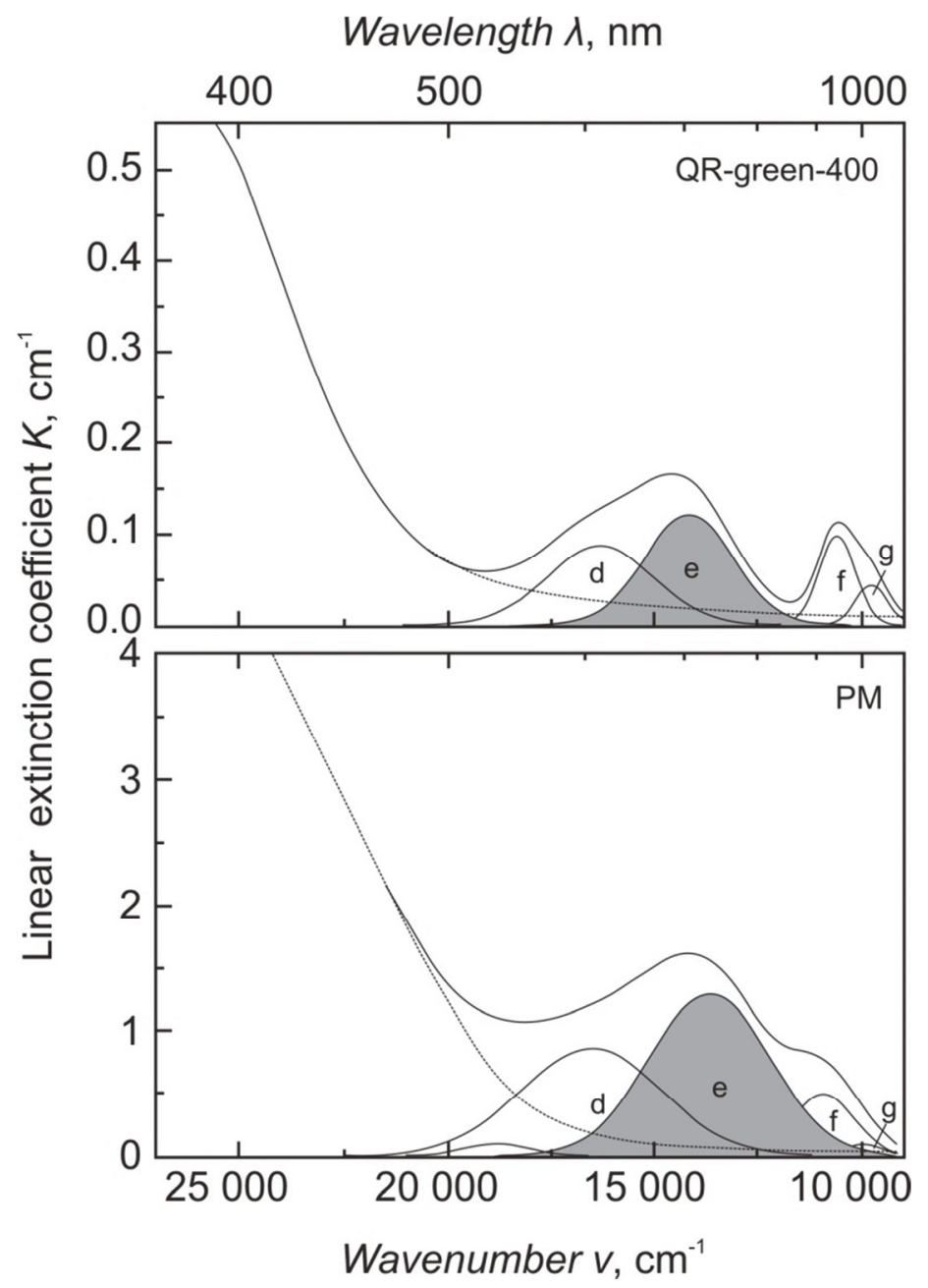

Fig. 4. The E\|c-polarized optical absorption spectra of the naturally coloured prasiolite (PM) from the Suszyna-Mrówieniec area and of the heated $\left(400^{\circ} \mathrm{C}\right)$ green quartz (QR-green-400) from Rakowice Wielkie. 
absorption spectrum of heat-treated QR-green (Fig. 4) becomes nearly identical to the spectrum of natural prasiolite PM (see also Platonov et al. 1992). In all Sudetic occurrences of prasiolite, quartz-agate geodes also contain pale-violet amethyst (Praszkier et al. 2011 and references therein). Thus amethyst seems to be an "end-member" of the colour series: amethyst - blue-green quartz (QR-blue) - pure-green quartz (QR-green) - prasiolite (PM).

As it has been emphasized by Hebert and Rossman (2008), through detailed spectral analyses, colour features in minerals may serve as indicators of changing dynamics as well as physical- and chemical characteristics of the mineral-forming system. The QR-blue, QRgreen and PM samples represent three closely related variants of hydrothermal quartz colouration. Thus, it seems that, apart from defining the location of maximum transmission of light (and the resultant colour), the variations in the relative intensities $c$-, $d$ - and $e$-bands also reflect differences in the physical- and chemical parameters of the mineral-forming hydrothermal fluids such as their chemical composition, particularly the presence of trace elements involved in the formation of colour centres (e.g., Al, Fe), temperature, oxygen fugacity, presence of radiation source, and others.

\section{Conclusions}

The following optical absorption bands, superimposed on the tail of the UV-band, were identified in the spectra of macrocrystalline quartzes from Rakowice Wielkie and the Suszyna-Mrówieniec area: $\sim 23,100 \mathrm{~cm}^{-1}$ and $\sim 21,200 \mathrm{~cm}^{-1}$ (both related to hole centres), the "amethyst band" $\sim 18,500 \mathrm{~cm}^{-1}$ (from a combination of a hole centre $\mathrm{Fe}^{4+}$ IV and an electron centre $\mathrm{Fe}^{2+}{ }_{\text {IV }}$ ), $\mathrm{A}_{1}$ band $\sim 16,250 \mathrm{~cm}^{-1}$ (attributed to $\mathrm{AlO}_{4}{ }^{4-}$ centres), the "prasiolite band" at $\sim 13,660 \mathrm{~cm}^{-1}$ (due to intervalence charge transfer $\mathrm{Fe}_{\mathrm{VI}}{ }^{2+} \rightarrow \mathrm{Fe}_{\mathrm{VI}}{ }^{3+}$ ) and $\sim 10,700$ $\mathrm{cm}^{-1}$ (from an electron centre $\mathrm{Fe}^{2+} \mathrm{vI}$ ).

The green colour of the quartzes results from the transmission "window" close to $18,500 \mathrm{~cm}^{-1}$. The exact position of the maximum transmission of light, and the resulting hue of the colouration, are defined by relative intensities of the superimposed "amethyst", $\mathrm{A}_{1}$ and "prasiolite" bands. The intense "prasiolite band" and weak "amethyst band" result in the maximum absorption at $\sim 14,050 \mathrm{~cm}^{-1}$ in the spectrum of the model prasiolite from the Suszyna-Mrówieniec area. Increasing intensity of the "amethyst band" and decreasing intensity of the "prasiolite band" shift the maximum transmission toward the higher wavenumbers (shorter wavelengths) inducing pale green and bluish-green colouration in different sectors of the Rakowice Wielkie quartz. It seems that pale-green and bluish-green colours of quartz from Rakowice Wielkie are intermediate colour varieties between amethyst and prasiolite.

Our study of three closely related variants of hydrothermal quartz colouration also indicate that, apart from trace elements, fluid inclusion and stable-isotope studies, optical absorption spectroscopy might be an important tool in characterizing physical- and chemical parameters of the mineral-forming system.

Acknowledgements. The authors thank Michał Sachanbiński for fruitful discussions and appreciate constructive reviews by three anonymous reviewers that helped to improve the final version of the manuscript. We also thank Stanisław Madej for taking the 
photographs of the samples. This work was supported by the University of Wrocław grant $1017 / \mathrm{S} / \mathrm{ING} / 2015$ to $\mathrm{ASz}$.

\section{References}

Awdankiewicz, M. (1999a). Volcanism in a late Variscan intramontane trough: Carboniferous and Permian volcanic centres of the Intra-Sudetic Basin, SW Poland. Geologia Sudetica, 32(1), 13-47.

Awdankiewicz, M. (1999b). Volcanism in a late Variscan intramontane trough: the petrology and geochemistry of the Carboniferous and Permian volcanic rocks of the Intra-Sudetic Basin, SW Poland. Geologia Sudetica, 32(2), 83-111.

Awdankiewicz, M. (2006). Fractional crystallization, mafic replenishment and assimilation in crustal magma chambers: geochemical constraints from the Permian post-collisional intermediate-composition volcanic suite of the North-Sudetic Basin (SW Poland). Geologia Sudetica, 38, 39-61.

Buksiński, S., \& Cegła, J. (1979). Kruszywa naturalne. In: Surowce mineralne Dolnego Śląska (ed. K. Dziedzic et al.). Zakład Narodowy im. Ossolińskich, Wrocław, 411-422. [in Polish]

Fiedler, H. (1863). Die Mineralien Schlesiens mit Berücksichtigung der angrenzenden Länder. Breslau: F.E.C. Leuckart. [in German]

Hebert, L. B., \& Rossman, G. R. (2008). Greenish quartz from the Thunder Bay Amethyst Mine Panorama, Thunder Bay, Ontario, Canada. The Canadian Mineralogist, 46, 111-124. DOI: 10.3749/canmin.46.1.111

Lehman, G. (1967). Farbzentren des Eisens als Ursache der Farbe von Amethyst. Zeitschrift für Naturforschung, 22a, 2080-2085. [in German]

Lehman, G. (1975). On the color centers of iron in amethyst and synthetic quartz: A discussion. American Mineralogist, 60, 335-337.

Lehman, G., \& Bambauer, H. U. (1973). Quarzkristalle und ihre Farben. Angewandte Chemie, 85(7), 281-289. [in German]

Madej, S. (1998). Petrologia permskich skał wulkanicznych okolic Tłumaczowa (Niecka Śródsudecka). Polskie Towarzystwo Mineralogiczne - Prace Specjalne, 11, 139-141. [in Polish]

Nassau, K., \& Prescott, B. E. (1977). Smoky, blue, greenish yellow, and other irradiation-related colors in quartz. Mineralogical Magazine, 41(319), 301-312.

Neumann, E., \& Schmetzer, K. (1984). Mechanism of thermal conversion of colour and colour centres by heat treatment of amethyst. Neues Jahrbuch für Mineralogie - Monatshefte, 6, 272-282.

Paradise, T. R. (1982). The natural formation and occurrence of green quartz. Gems and Gemology, 18, 39-42.

Partlow D. P., \& Cohen A. J. (1986). Optical studies of biaxial Al-related color centers in smoky quartz. American Mineralogist, 71, 589-598.

Platonov, A. N., Sachanbiński, M., Wróblewski, P., \& Ignatov S. I. (1991). Rare varieties of green quartz from quartz-agate geodes in Lower Silesia, Poland. Mineralogicheskiy Zhurnal, 13, 10-17. [in Russian]

Platonov, A. N., Sachanbiński, M., Wróblewski, P., \& Ignatov S.I. (1992). Natural prasiolite from Lower Silesia, Poland. Zeitschrift der Deutsche Gemmologische Gesellschaft, 41(1), 21-27.

Praszkier, T., Bogdański, J., Siuda, R., \& Sachanbiński, M. (2011). Agates from Płóczki Górne, Lower Silesia, Poland. Warszawa: Spirifer Geological Society.

Praszkier, T., Kenis, P., \& Komza, P. (2015). Prasiolite from Sokołowiec area, Kaczawskie Mountains, Lower Silesia, Poland. Retrieved June 21 2015, from http://www.spiriferminerals.com/163,New-prasiolite-find-Poland.html

Rossman, G. R. (1994). Colored varieties of the silica minerals. In P.J. Heaney, C.T. Prewitt \& G.V. Gibbs (Eds.), Silica: Physical behaviour, geochemistry and materials applications. Reviews in Mineralogy, 29 (pp. $433-$ 467). Washington, D.C.: The Mineralogical Society of America.

Sachanbiński, M., Płatonow, A. N., \& Jezierski, A. (1994). Nowe dane o prasiolicie. Polskie Towarzystwo Mineralogiczne-Prace Specjalne, 5, 197-199. [in Polish]

Schmetzer, K. (1989). Methods for the distinction of natural and synthetic citrine and prasiolite. Journal of Gemmology, 21(6), 368-391. DOI: 10.15506/JoG.1989.21.6.368. 